\title{
Defusing Theological Dynamite
}

\section{Predestination and Divine Love in the Summa Halensis}

\begin{abstract}
Aiming partially to fill a significant lacuna in the scholarship on scholastic understandings of predestination, this essay seeks to show that the doctrine set forth in the Summa Halensis, though dependent upon Augustine's well-known definition, diverges essentially from the African bishop's mature teaching. Specifically, the Summa teaches that predestination is God's eternal 'volitional knowledge' of those humans who will, by their free wills, use grace well to attain finally to glory. In contradistinction to the popular modern perspective that sees predestination as arbitrary and irrational, the Summa understands God's 'volitional knowledge' as perfectly 'rational' (rationabilis) precisely in that it carves out room for the human to will freely and to participate authentically in God's salvific plan. In this way, the Summa served to defuse the theological dynamite of the late Augustine's predestinarian teaching.
\end{abstract}

Predestination stands as one of the most constitutive doctrines of the Catholic theological tradition and, at the same time, has been one of the most misunderstood and controversial among modern commentators. ${ }^{1}$ In his assessment of Augustine's theological influence, the prominent English church historian W.H.C. Frend, for example, maintained that the Bishop of Hippo 'left the Middle Ages with a theological legacy of arbitrary predestination, which sacrificed the vast majority of mankind to everlasting torment in the name of the righteousness of an inscrutable God.'2 For Frend, Augustine was a 'crusted old pessimist' concerning post-lapsarian human nature and free will, which led him to develop a doctrine of predestination whose essence was 'fatalism unrelieved'. ${ }^{3}$ Like most people today who give any thought whatsoever to predestination, Frend betrays an understanding of the doctrine that generally aligns with the definitive Reformed interpretation propounded by John Calvin and codified at the Dutch Synod of Dordrecht, or Dort, in $1619 .{ }^{4}$ According to this Calvin-

1 For a brief introduction to the doctrine that notes some of the contemporary difficulties and confusions, see Matthew Levering, Predestination: Biblical and Theological Paths (Oxford: Oxford University Press, 2011). For a fuller consideration, see Peter J. Thuesen, Predestination: The American Career of a Contentious Doctrine (Oxford: Oxford University Press, 2009).

2 W.H.C. Frend, The Early Church (Minneapolis: Fortress Press, 1982), 198.

3 Frend, The Early Church, 207.

4 See John Calvin, Institutes of the Christian Religion III, chs. 21-2, ed. John T. McNeill, trans. Ford Lewis Battles, Library of Christian Classics, 21 (Philadelphia: Westminster Press, 1960), 920 - 47; and Carlos M.N. Eire, Reformations: The Early Modern World, 1450-1650 (New Haven: Yale University Press, 2016), 295-6 and 572-4. The Synod of Dort affirmed double predestination and proposed a doctrinal summary that came to be known as Five-Point Calvinism, which can easily be memorized 
ist view, the eternally existent God actively and inscrutably wills either salvation or reprobation for each human before all time and supervenes upon human freedom such that each one is ineluctably moved by divine imperative toward either final salvation (and the grace such movement requires) or everlasting damnation (and the grave sin it demands). ${ }^{5}$

Calvin and his followers did not create this understanding out of whole cloth, of course. They intended themselves as faithful disciples of both Scripture and Augustine. And, indeed, their doctrine is generally thought to comport with that of the late Augustine in particular-the Augustine who disputed with the Pelagians from 412 onward. The Calvinist doctrine is, to use Gerald Bonner's description, 'essentially Augustinian theology'. ${ }^{6}$ In such late anti-Pelagian writings as Contra Iulianum (c. 422), De praedestinatione sanctorum (c. 429), and De dono perseverantiae (c. 429), for example, Augustine definitively rejects the notion that God elects based on foreseen merits. ${ }^{7}$ Recognizing that Scripture and the theological tradition sometimes designate predestination by the name foreknowledge, Augustine denies that divine predestination is reducible to what God eternally knows each human will do with the gifts of faith and grace that God might provide. Predestination is not simply or primarily God's foreknowledge of what humans are going to do; rather, it is foreknowledge of what God Himself is going to do. Augustine's teaching here effectively ensures that predestination is wholly dependent on an immutable and inscrutable divine agency. ${ }^{8}$ 'God's gratuitous initiative in the predestination of people ends up in an apartheid-like form of salvation,' Donato Ogliari notes, 'reserved to the

by means of the acronym TULIP: Total depravity, Unconditional election, Limited atonement, Irresistible grace, and Perseverance of the saints (Eire, Reformations, 572).

5 See Thomas Joseph White, 'Catholic Predestination: The Omnipotence and Innocence of Divine Love,' in Thomism and Predestination: Principles and Disputations, ed. Steven A. Long, Roger W. Nutt, and Thomas Joseph White (Ave Maria, FL: Sapientia Press, 2016), 94-126, esp. 97; and Herbert McCabe, 'Predestination,' in Herbert McCabe, God Still Matters, ed. Brian Davies (London: Continuum, 2002), 182-6, who summarizes the Calvinist view thus: 'So it looks as though each one of us is born with a destiny. (...) And God has arranged all this beforehand; there is obviously nothing we can do to alter our destinies. Whether we get to heaven or not, it seems, has nothing to do with what we choose to do: it has all been fixed beforehand by God' (McCabe, 'Predestination,' 182). 6 Gerald Bonner, Freedom and Necessity: St. Augustine's Teaching on Divine Power and Human Freedom (Washington, DC: The Catholic University of America Press, 2007), 14.

7 See, e.g., Augustine, Contra Iulianum 5.4.14 (PL 44:791-93); Augustine, De praedestinatione sanctorum 10.19 (PL 44:974-75); and Augustine, De dono perseverantiae 18.47 (PL 45:1022-23). In De praedestinatione sanctorum 3.7 (PL 44:964-65), Augustine explains that his current view represents a break with his former thinking, set forth in such works as Expositio quarundam propositionum ex epistula apostoli ad Romanos 60 (c. 395; PL 35:2078 - 79), according to which God chooses to give grace to those humans whom He foreknows will have faith so that, by performing good works, they might attain to eternal life.

8 See Donato Ogliari, Gratia et certamen: The Relationship between Grace and Free Will in the Discussion of Augustine with the So-called Semipelagians (Leuven: Leuven University Press, 2003), 330 - 4. 
happy few whom God has decided to endow with the invincible strength of his grace. ${ }^{9}$

Because it seems completely to preclude human freedom and thus genuine human participation in salvation, Augustine's mature doctrine of predestination has been roundly critiqued as unjust, unnatural, and even dangerous. James Wetzel explains: 'Augustine's doctrine of predestination, founded on his premise of unearned election, has been akin to theological dynamite. To preach this doctrine is to invite revolution and retrenchment, license and rebuke.' ${ }^{10}$ Gerald Bonner's harsh judgment provides testimony to its explosive potential: 'Nothing is gained by attempting to defend the doctrine, which remains a terrible one and more likely to arouse our awe than enlist our sympathy. ${ }^{11}$ In his book-length treatment of Augustine on predestination, Bonner puzzles over how so great and wide-ranging an intellect was unable, or unwilling, to transcend 'so narrow a view of the divine purpose for the greater part of humanity'. ${ }^{12}$ Among the handful of possible explanations he offers is that Augustine tended to address himself to one or more theological issues separately rather than to the construction of a single, comprehensive system that sought to harmonize or reconcile the range of scriptural and theological teachings. Augustine was never moved to pen 'a summa theologiae augustinianae', a fact that Bonner finds greatly regrettable. ${ }^{13}$

Scholars seeking to trace lines of influence concerning predestination-and a constellation of concomitant philosophical and theological issues-from Augustine to the high and late Middle Ages have focused largely on Aquinas and the subsequent Thomistic tradition, on the one hand, or on Franciscan theologians who flourished after the mid $13^{\text {th }}$ century, such as Bonaventure, John Duns Scotus, William of Ockham, and Peter Auriol, on the other. ${ }^{14}$ Consequently, we still have much to learn

9 Ogliari, Gratia et certamen, 333.

10 James Wetzel, 'Snares of Truth: Augustine on Free Will and Predestination,' in Augustine and his Critics: Essays in Honour of Gerald Bonner, ed. Robert Dodaro and George Lawless (London: Routledge, 2000), 124.

11 Gerald Bonner, St. Augustine of Hippo: Life and Controversies (London: SCM Press, 1963), 392, quoted in Wetzel, 'Snares of Truth,' 124.

12 Bonner, Freedom and Necessity, 132; see also Bonner, Freedom and Necessity, 15.

13 Bonner, Freedom and Necessity, 132.

14 See, e. g., Jean-Pierre Arfeuil, 'Le dessein sauveur de Dieu: La doctrine de la prédestination selon saint Thomas d'Aquin,' Revue thomiste 74 (1974): 591-641; Michał Paluch, La profondeur de l'amour divin: Évolution de la doctrine de la prédestination dans l'œuvre de saint Thomas d'Aquin (Paris: J.Vrin, 2004); Harm Goris, 'Divine Foreknowledge, Providence, Predestination, and Human Freedom,' in The Theology of Thomas Aquinas, ed. Rik Van Nieuwenhove and Joseph Wawrykow (Notre Dame, IN: University of Notre Dame Press, 2005), 99-122; Andreas Speer, 'Divine Government and Human Freedom,' in Fate, Providence and Moral Responsibility in Ancient, Medieval and Early Modern Thought: Studies in Honour of Carlos Steel, ed. Pieter d'Hoine and Gerd Van Riel (Leuven: Leuven University Press, 2014), 517-37; Rudi te Velde, 'Thomas Aquinas on Providence, Contingency and the Usefulness of Prayer,' in Fate, Providence and Moral Responsibility, 541-52; Pasquale Porro, 'Divine Predestination, Human Merit and Moral Responsibility: The Reception of Augustine's Doctrine of Irresistible 
about predestinarian doctrine in the period between the mid $12^{\text {th }}$ century, when Peter Lombard penned the Sentences, and the mid $13^{\text {th }}$ century, when Aquinas and Bonaventure produced formal commentaries on the Lombard's book. This historical rift in scholarly understanding is intimated by Susan Schreiner and Jeremy Thompson who, in their 2013 treatment of the medieval reception of Augustine's doctrine, move directly from the Lombard to Aquinas. ${ }^{15}$ The present essay aims partially to fill this significant lacuna in the scholarship by considering predestination and divine love in the Summa Halensis (SH). Through an analysis of several questions in the $S H$ on the nature and objects of predestination, I seek to show that the Halensian doctrine, though dependent upon Augustine's well-known definition, diverges essentially from the African bishop's mature teaching. Specifically, the $S H$ teaches that predestination is God's eternal 'volitional knowledge' of those humans who will, by their free wills, use grace well to attain finally to glory. If Frend's claim-that Augustine bequeathed an 'arbitrary' doctrine to the Middle Ages-is correct, the early-Franciscan Summists seem to have been less than entirely satisfied with what they had received. Indeed, I will demonstrate, contra Frend, that the $S H$ understands God's predestination as perfectly 'rational' (rationabilis) precisely in that it carves out room for the human to will freely and to participate authentically in God's salvific plan. In this fundamental way,

Grace in Thomas Aquinas, Henry of Ghent and John Duns Scotus,' in Fate, Providence and Moral Responsibility, 553-70; the essays collected in Long, Nutt, and White (eds), Thomism and Predestination: Principles and Disputations (see above, n. 5); Klaus Obenauer, Electio e sinu Trinitatis: Bonaventuras Prädestinationslehre nebst einem Reflexionsbeitrag (Hamburg: Kovač, 1996); Franklin T. Harkins, 'The Early Aquinas on the Question of Universal Salvation, or How a Knight May Choose Not to Ride His Horse,' New Blackfriars 95 (2014): 208 - 17; Franklin T. Harkins, 'Contingency and Causality in Predestination: 1 Tim. 2:4 in the Sentences Commentaries of Albert the Great, Thomas Aquinas, and John Duns Scotus,' Archa Verbi 11 (2014): 35-72; Wolfhart Pannenberg, Die Prädestinationslehre des Duns Skotus: im Zusammenhang der scholastischen Lehrentwicklung (Göttingen: Vandenhoeck \& Ruprecht, 1954); Allan B. Wolter, 'Scotus' Paris Lectures on God's Knowledge of Future Events,' in The Philosophical Theology of John Duns Scotus, ed. Marilyn McCord Adams (Ithaca, NY: Cornell University Press, 1990), 285-333; Cruz González-Ayesta, 'Duns Scotus on Synchronic Contingency and Free Will: The Originality and Importance of his Contribution,' in Proceedings of 'The Quadruple Congress' on John Duns Scotus, vol. 1, John Duns Scotus, Philosopher, ed. Mary Beth Ingham and Oleg Bychkov (Münster: Aschendorff, 2010), 157-74; J.J. McIntosh, 'Aquinas and Ockham on Time, Predestination and the Unexpected Examination,' Franciscan Studies 55 (1998): 181-220; Tetsuro Shimuzuo Shimizu, 'Time and Eternity: Ockham's Logical Point of View,' Franciscan Studies 50 (1990): 283-307; James L. Halverson, 'Franciscan Theology and Predestinarian Pluralism in Late-Medieval Thought,' Speculum 70 (1995): 1-26; James L. Halverson, Peter Aureol on Predestination: A Challenge to Late Medieval Thought (Leiden: Brill, 1998); Christopher Schabel, Theology at Paris 1316-1345: Peter Auriol and the Problem of Divine Foreknowledge and Future Contingents (Aldershot: Ashgate, 2000); Christopher Schabel, 'Parisian Commentaries from Peter Auriol to Gregory of Rimini, and the Problem of Predestination,' in Mediaeval Commentaries on the Sentences of Peter Lombard, vol. 1, Current Research, ed. G.R. Evans (Leiden: Brill, 2002), 221-65.

15 Susan E. Schreiner and Jeremy C. Thompson, 'Predestination,' in The Oxford Guide to the Historical Reception of Augustine, vol. 3, ed. Karla Pollmann et al. (Oxford: Oxford University Press, 2013), 1594. 
the $S H$ served to defuse the theological dynamite of the late Augustine's predestinarian teaching.

As the topics treated in the four books of the $S H$ generally follow those of the Lombard's four books of Sentences (viz. the Triune God, creation, the Incarnation of the Word, and sacraments and Last Things), here predestination is taken up within a broader consideration of divine knowledge, which constitutes Tractate 5 (De scientia divina) of the First Inquiry of the First Part of Book 1. Book 1 is divided into two major parts: the Prima Pars concerns 'the unity and trinity of the deity ordered to the heart's belief', whereas the Secunda Pars treats 'the unity and trinity of the deity ordered to the mouth's confession'. Following the Introductory Tractate on the teaching of theology (De doctrina theologiae) and the human's knowledge of God in this life (De cognitione Dei in via), the prologue to the First Inquiry (Inquisitio Prima) makes clear the scriptural roots of this basic bifurcation of Book 1: 'There are two parts of this investigation, according to the words of the Apostle in Rom. 10, 20 [sic], "One believes with the heart for justice, but confesses with his mouth for salvation". ${ }^{16}$ The First Inquiry of the Prima Pars treats the substance of divine Unity (De substantia divinae Unitatis), whereas the Second Inquiry treats the plurality of divine Trinity (De pluralitate divinae Trinitatis). The consideration of the divine unity that constitutes the First Inquiry is divided into six tractates, which concern: divine essentiality, immutability, and simplicity (Tractate 1); the immeasurability (immensitate) of the divine essence (Tractate 2); divine unity, truth, and goodness (Tractate 3); divine power (Tractate 4); divine knowledge (Tractate 5); and divine will (Tractate 6). The Second Part of Book 1, on divine unity and Trinity ordered to the mouth's confession, is also divided into two Inquiries, the first of which concerns the divine names in general (De divinis nominibus in generali) and the second the divine names in particular (De divinis nominibus in speciali). Predestination's place within this overall structure of Book 1 indicates that the Summists understand this doctrine not only as having to do in the first instance with God's knowledge (as opposed to God's power or will), but also as a topic falling fundamentally within the realm of the human reader's belief toward justice (rather than his verbal confession or discourse about God toward salvation). We are in the highly speculative realm of knowing God (and, more specifically, of knowing God's knowing), as best we can in this life, rather than of naming God, which would seem somewhat easier based on more data-and more straightforward data-received from revelation (e.g. Deus, persona, hypostasis, Pater, Filius, Imago, Spiritus Sanctus).

16 Alexander of Hales, Doctoris Irrefragabilis Alexandri de Hales Ordinis minorum Summa theologica $(\mathrm{SH}), 4$ vols (Quaracchi: Collegium S. Bonaventurae, 1924-48), Vol I, P1, In1, p. 39: 'Cuius inquisitionis duae sunt partes, secundum verbum Apostoli, Rom. 10, 20 [sic]: "Corde creditur ad iustitiam, ore autem a confessio fii ad salutem".' Interestingly, the edition wrongly cites this Pauline passage as Rom. 10:20; the correct citation is, in fact, Rom. 10:10. 
In Tractate 5, after treating of the knowledge of God considered absolutely, the $\mathrm{SH}$ turns to the knowledge of God considered relatively: relative to future events (i.e. divine foreknowledge), relative to things to be done or made (i.e. the divine dispensation), relative to things to be managed or directed (i.e. divine providence), and relative to those to be saved (i.e. divine predestination). Here in the preface to the treatment de scientia Dei relate ad salvanda, the Summists make clear the lack of clarity in-and the potential for confusion concerning-the basic scriptural and theological vocabulary related to God's knowledge and will vis-à-vis salvation:

Following an order, and with the Lord helping us, we must inquire about predestination and its opposite, namely reprobation, and at the same time divine election and love. For predestination assumes election and love; for everyone who is predestined by God has been chosen and loved, but is not converted [to God]. For someone is called elect only insofar as his present justice is concerned, such as Judas, although he is reprobate. Similarly, everyone who is elect has been loved, but is not converted [to God]. For election considers grace, but love considers not only grace but nature as well; grace, however, assumes nature, but nature does not assume grace. Hence someone who is still evil on account of nature is said to be loved. Therefore, predestination always looks to glory; election does not always look to glory, but always to grace; love does not always look to grace or glory, but always to nature. ${ }^{17}$

The hierarchy of terms set forth here explains how divine love and election, though necessary to predestination, are in themselves insufficient for it: one can be loved, which is according to nature, and chosen, which merely indicates his or her present justice, without being turned finally back to God. Love can be spoken of only with regard to nature, and election only with regard to grace; predestination alone, however, indicates something about the human person's relation to glory.

When the Summists open their consideration in Membrum 1 with the question, 'What is predestination?', they divide the question into three chapters: 1 . what is it according to name; 2 . what according to the nature of understanding (secundum rationem intelligentiae); and 3. what according to reality. The treatment of predestination secundum nomen begins with some of the key scriptural passages that introduce the vocabulary of predestination, election, and love. Those who will be saved are said to be predestined and loved, as in Mal. 1:2, 'Jacob have I loved', and elect or chosen, as in Rom. 11:5, 'a remnant will be saved according to election'; they are also said to be called, justified, and glorified, as in Rom. 8:30: 'Those whom He pre-

17 SH I, P1, In1, Tr5, S2, Q4, Ti1, p. 315: 'Ordine consequenti, adiuvante Domino, quaerendum est de praedestinatione et eius opposito, scilicet reprobatione, simulque de divina electione et dilectione. Praedestinatio enim divina ponit electionem et dilectionem; omnis enim praedestinatus a Deo est electus et dilectus, sed non convertitur: electus enim aliquis dicitur tantum quantum ad praesentem iustitiam, sicut Iudas, quamvis sit reprobus; item, omnis electus est dilectus; haec non convertitur: electio enim respicit gratiam, dilectio vero non solum gratiam, sed naturam; gratia autem ponit naturam, sed natura non ponit gratiam: unde dilectus dicitur adhuc qui malus est ratione naturae. Praedestinatio ergo semper respicit gloriam; electio non semper respicit gloriam, sed semper gratiam; dilectio non semper gratiam vel gloriam, sed semper naturam.' 
destined, he also called; and those whom He called, He also justified; and those whom He justified, He also glorified.' Such passages as Mal. 1:2 and Rom. 8:30 indicate that predestination is from eternity, whereas calling, justification, and glorification take place in time. Love and election, by contrast, are both eternal and temporal realities. Mal. 1:2 indicates the eternal nature of God's love, whereas Christ's words in John 14:21 intimate its temporal aspect: 'He who loves me will be loved by my Father.' Similarly, Matt. 20:16, 'Few are chosen', points to election from eternity, whereas John 6:71 highlights its temporality: 'Have I not chosen you twelve, and one of you is a devil?' This one was Judas, of course, who was elect, the SH notes. ${ }^{18}$ Though it is not stated explicitly here, the reader is left to conclude that Judas-though electwas not among those predestined, reinforcing the points that: 1. predestination is strictly eternal; and 2. election, with both temporal and eternal aspects, is a necessary but insufficient condition for predestination.

In responding to the question of what predestination is according to name, the Summists explain predestination, love, and election vis-à-vis eternality and temporality by understanding each of these terms in relation to grace. Grace itself can be considered in three ways: as given or conferred, as received, and as used. Predestination considers what is conferred by grace, love looks to grace received, and election pertains to the use of grace. ${ }^{19}$ It is the prefix 'pre-' that accounts for the strictly eternal nature of predestination, as does its consideration of what is conferred by grace. The Summists explain:

There are two things in the word "predestination": a going before and a destination. And in the destination there are three things: for it is necessary that it is of someone, from something, and to something. Therefore, there are three things in predestination: [1] one [is described] as the beginning, namely the "preparation", from which it is; [2] "of glory in the future" designates the end to which it is; [3] "of grace in the present" designates the middle through which it is. Thus, the destination is designated according to time, but predestination, by reason of the going before, is eternal. For this preposition "pre-" indicates the going before in relation to time. ${ }^{20}$

Whereas the 'destination' in 'predestination' indicates one's movement from one thing to another and, as such, is temporal, the 'pre-' signifies the antecessio, the be-

18 SH I, P1, In1, Tr5, S2, Q4, Ti1, M1, C1 (n. 220), pp. 315-6.

19 SH I, P1, In1, Tr5, S2, Q4, Ti1, M1, C1 (n. 220), Respondeo, p. 316.

20 SH I, P1, In1, Tr5, S2, Q4, Ti1, M1, C1 (n. 220), Respondeo, p. 316: 'In nomine praedestinationis duo sunt: antecessio et destinatio, et in destinatione tria: oportet enim quod sit alicuius et de aliquo et ad aliquid. Et ideo in praedestinatione sunt tria: [1] unum ut principium, scilicet 'praeparatio', a quo est; quod dicitur [2] 'gloriae in futuro', dicit ut terminum ad quem est; quod dicitur [2] 'gratiae in praesenti', dicit ut medium quod est; destinatio ergo dicitur ex tempore; sed praedestinatio ratione antecessionis est aeterna: haec enim praepositio 'prae' dicit antecessionem aeternitatis ad tempus.' As we will see below, here the authors have in view Augustine's famous definition of predestination as 'the preparation of grace in the present and of glory in the future', which they quote explicitly in part in SH I, P1, In1, Tr5, S2, Q4, Ti1, M1, C2 (n. 221), Contra 1, p. 316, and in full in SH I, P1, In1, Tr5, S2, Q4, Ti1, M1, C3 (n. 222), arg. 1, p. 318. 
ginning of or preparation of grace and glory that is in God eternally. The author further describes this antecessio thus: 'I say that predestination designates the eternal approbation of God as it is with respect to the good, even before all time. ${ }^{21}$

With this nominal understanding in view, Chapter 2 proceeds to ask what predestination is according to the nature of understanding (secundum rationem intelligentiae). The question here is that of the intellectual category to which predestination fundamentally belongs: that is, does it have to do principally with God's knowledge, will, or power? The solution makes clear that predestination falls primarily within the category of divine knowledge, though it is not a matter of God's simple knowledge (scientia simplex). Rather, being 'in the genus of the knowledge of [God's] good will or approbation', ${ }^{22}$ it straddles divine knowledge and will, though it leans more toward the former. The Summists state it somewhat differently when they note that in the phrase, 'knowledge of good will or approbation', knowledge is understood directly and will or approbation obliquely. ${ }^{23}$ Drawing this distinction between simple knowledge, which the $S H$ understands as 'in the speculative mode', on the one hand, and what I will call 'volitional knowledge', which is 'in the practical mode', on the other, enables the Summists to carve out room for both divine and human causation. Whereas simple knowledge cannot be said to be a (or the) cause of those things that are known, knowledge with or of approbation is a (or the) cause of the known in this case, that is, of things or persons approved..$^{24}$ It is divine approval by which the approved are approved, and the approved are approved and known to be approved eternally: this is, as we have seen, simply what predestination is, according to the $\mathrm{SH}$.

This leads quite naturally, then, to the question of what predestination is in reality (secundum rem), which is taken up in Chapter 3. The starting point is Augustine's well-known definition: 'Predestination is the preparation of grace in the present and of glory in the future. ${ }^{25}$ The language of this definition reminds the reader of the eternal and temporal aspects of predestination. Objection 1 explains: if grace is in the present, it is clearly not from eternity; then neither is the preparation of such grace from eternity; thus, predestination appears not to be from eternity. ${ }^{26}$ The second objection follows from the first, explaining that if an architect or craftsman is said to 'prepare' a house that is to be built, he must have those things that

21 SH I, P1, In1, Tr5, S2, Q4, Ti1, M1, C1 (n. 220), Respondeo, p. 316: ‘(...) dico quod praedestinatio dicit approbationem Dei aeternam, secundum quod est respectu boni, etiam ante omne tempus.'

22 SH I, P1, In1, Tr5, S2, Q4, Ti1, M1, C2 (n. 221), Solutio, p. 317: 'Ad hoc dicendum quod praedestinatio est in genere scientiae beneplaciti sive approbationis.'

23 SH I, P1, In1, Tr5, S2, Q4, Ti1, M1, C2 (n. 221), Solutio, p. 317: 'In scientia beneplaciti vel approbationis intelligitur scientia in rectitudine et voluntas sive approbatio in obliquitate.'

24 SH I, P1, In1, Tr5, S2, Q4, Ti1, M1, C2 (n. 221), Solutio, p. 317.

25 See Augustinus, De praedestinatione sanctorum 10.19 (PL 44:974), where Augustine sets forth the first half of this definition.

26 SH I, P1, In1, Tr5, S2, Q4, Ti1, M1, C3 (n. 222), arg. 1, p. 318. 
pertain to the actual construction or existence of the house, such as wood and stones. By analogy, if predestination is the preparation of grace from eternity, it is necessary that there be something from eternity that pertains to the grace that is going to be prepared. But its preparation is not from eternity precisely because 'nothing about grace is said to have been from eternity'. ${ }^{27}$ Similarly, Objection 3 asks what the basis for the preparation from eternity is, observing that although a craftsman has the knowledge to build a house and the will to do it, such knowledge and will are not described as his 'preparation' of the house. By analogy, if God eternally knows and wills with respect to someone to whom grace is going to be given in the present because this person finally is going to use it well, the preparation of grace is not said to be on account of this foreknowledge and fore-willing. ${ }^{28}$

Significantly in the light of these objections, the respondeo neither dismisses nor further questions Augustine's definition as a, or indeed the, way to understand predestination according to reality (secundum rem). Rather, it distinguishes between two senses of the word 'preparation', one temporal and the other eternal:

\footnotetext{
"Preparation" is used in two ways: for it is called "preparation" when grace is given and before it is given, namely when there is knowledge that someone finally is going to use it well and when there is the will to give it to him. Used in the first way, inasmuch as it concerns grace having been prepared, it is also called temporal preparation. In the second way, it is called eternal preparation because used in this way it brings in the will from eternity, that is, the will of Him who is going to give grace to that person with foreknowledge that that person finally is going to use it well. ${ }^{29}$
}

Satisfied that this distinction provides a clear solution to the first objection, the Summists turn immediately to the second. There is not at all an exact parallel between a human craftsman and God, they explain, because the human craftsman is not sufficient in himself for all of his activity; rather, he must rely on material external to himself, like wood and stone, to complete his work. 'The Highest Craftsman,' by contrast, 'has the power of working without matter.' ${ }^{30}$ Even in those cases where the divine

27 SH I, P1, In1, Tr5, S2, Q4, Ti1, M1, C3 (n. 222), arg. 2, p. 318: ‘ergo si praedestinatio est praeparatio gratiae ab aeterno, oportet quod ab aeterno sit aliquid de re praeparanda; sed nihil de gratia dicitur ab aeterno fuisse; ergo praeparatio huius non fuit ab aeterno.'

28 SH I, P1, In1, Tr5, S2, Q4, Ti1, M1, C3 (n. 222), arg. 3, p. 318.

29 SH I, P1, In1, Tr5, S2, Q4, Ti1, M1, C3 (n. 222), Respondeo, p. 318: 'Praeparatio dicitur dupliciter: praeparatio enim dicitur cum datur gratia et antequam detur, scilicet cum est scientia quod aliquis bene usurus est finaliter et est voluntas dandi ei. Secundum primum modum, quantum est ex parte praeparatae gratiae, quod est connatatum dicitur praeparatio temporalis; secundum modum secundum dicitur aeterna praeparatio, quia hoc modo importat voluntatem ab aeterno, voluntatem scilicet dandi isti gratiam cum praescientia quod bene sit usurus ea finaliter.'

30 SH I, P1, In1, Tr5, S2, Q4, Ti1, M1, C3 (n. 222), Ad obiecta 2, p. 318: 'Ad secundum dicendum quod non est simile de artifice homine et de Deo, quia artifex homo non est sibi sufficiens ad totam suam operationem, et ideo requirit materiam subiectam; artifex Deus sibi per omnia est sufficiens nec indiget materia subiecta; unde Artifex summus habet vim agenda sine materia.' 
action has to do with matter, God can operate either with or without it. As such, God's 'preparation' is never dependent on any material thing; rather, divine 'preparation' designates any operation in which God's wisdom, knowledge, and will concur. Over against the assertion in Objection 2 that 'nothing about grace is from eternity', the Summists affirm that, though this is true of the effects of grace, it is by no means true of its cause. ${ }^{31}$ They conclude by briefly noting that the solution to Objection 3 is clear from the response to Objection 2. Because God, unlike the human craftsman, requires nothing external to Himself for His operations, His knowledge and will (together with His wisdom, of course) concerning those who are to be saved constitute His 'preparation'.

Having established what predestination is according to name, understanding, and reality, the $\mathrm{SH}$ moves, in Membrum 2, to a consideration of quorum sit praedestinatio, of what or whom predestination is, that is, to what realities or beings as objects it pertains. This inquiry consists of six questions, five of which are treated here: 1. whether it is of being or non-being; 2 . whether it is of all [humans]; 3. whether it can be of the reprobate; 4 . whether it is of angels; 5 . whether it is of the blessed; and 6 . whether it is of Christ (treated in Book 3, on the Incarnation of Christ). Presently we can consider only the first two of these questions. The apparent paradox that predestination is both eternal and of a creature provides the occasion for the Summa's asking whether predestination is of being or of non-being. Because no creature exists from eternity, predestination would appear to be of non-being, the sole objection notes. ${ }^{32}$ Following the contra, which draws on the teaching of Origen and Augustine that predestination has to do with the destining of someone or something that exists, the respondeo answers based on a distinction concerning ens, being or existence. A thing is called a 'being' either in its proper nature or in the foreknowledge or foreordination of God, the Summists explain:

The being of a thing in its proper nature is not eternal, but temporal. But the being of a thing in foreknowledge or in fore-ordination is eternal and does not differ from the divine being, because this kind of being of a thing is not other than the being of an eternal idea or reason in God. The being of a thing in its own nature is being simply (simpliciter), [whereas] the being of a thing in its cause or in foreknowledge is the being of a thing according to something (secundum quid). ${ }^{33}$

Predestination is said, then, with respect to a thing 'being' in its cause or in divine foreknowledge, but not with respect to a thing existing in its own proper nature. This means that predestination can be said with respect to a thing of being according

31 SH I, P1, In1, Tr5, S2, Q4, Ti1, M1, C3 (n. 222), Ad obiecta 2, p. 318.

32 SH I, P1, In1, Tr5, S2, Q4, Ti1, M2, C1 (n. 223), arg. 1, p. 318.

33 SH I, P1, In1, Tr5, S2, Q4, Ti1, M2, C1 (n. 223), Respondeo, p. 319: 'Esse rei in propria natura non est aeternum, sed temporale; sed esse rei in praescientia sive in praeordinatione est aeternum et non differens ab esse divino, quia esse rei huiusmodi non est aliud quam esse ideae sive rationis aeternae in Deo; esse rei in sua natura est esse simpliciter, esse rei in causa sive in praescientia est esse rei secundum quid.' 
to something (secundum quid), and with respect to a thing of non-being simply (simpliciter). ${ }^{34}$ One example, which the $S H$ itself does not offer, may prove helpful here. Predestination, which is eternal, pertains to the being of Peter secundum quid, that is, in his being in divine foreknowledge; but it does not pertain to his being simpliciter precisely because he does not exist in his own proper nature eternally. We must say that predestination, because it is eternal, generally (not only in the particular case of Peter) pertains to non-being if being is considered simpliciter, that is, in its own proper nature.

Having established that predestination pertains to beings as they exist in the divine foreknowledge, the $S H$ moves, in Chapter 2, to the question 'whether predestination is of all'. Following from the discussion in Chapter 1, the reader may assume that the omnium here refers to all beings, as existing in the mind of God. However, the first objection's introduction of 1 Tim. 2:4, 'God wills that all humans should be saved', narrows the field of inquiry considerably. ${ }^{35}$ If God wills that all human beings should be saved, predestination seems to be of all humans. Interestingly, however, without citing any authority, the contra states matter-of-factly: 'Not all will be saved; therefore not all have been predestined. ${ }^{36}$ The contra takes it as a foregone conclusion-in light of the scriptural evidence, Augustinian teaching, and the intervening theological tradition-that every human will not be saved, and thus that every human is not predestined. Building on the earlier distinction between divine knowledge and will and on the explanation of 'preparation' in God, the respondeo opens thus:

Foreknowledge orients itself equally toward all; similarly, the will orients itself in one way toward all. But the will with foreknowledge does not orient itself equally toward all. This is not, however, on account of [any] difference that is in foreknowledge, but because we do not orient ourselves equally to it. Hence predestination designates not merely the will of God, but His will with foreknowledge that they [i.e. predestined humans] are going to use their good gift well. ${ }^{37}$

Simultaneously affirming that the divine will orients itself only in one way toward all humans and that this same will with foreknowledge of human free will does not enables the Summists effectively to introduce the classic distinction of John Damascene between God's antecedent and consequent will as a lens through which to read 1

34 SH I, P1, In1, Tr5, S2, Q4, Ti1, M2, C1 (n. 223), Respondeo, p. 319.

35 SH I, P1, In1, Tr5, S2, Q4, Ti1, M2, C2 (n. 224), arg. 1, p. 319.

36 SH I, P1, In1, Tr5, S2, Q4, Ti1, M2, C2 (n. 224), Contra, p. 320: 'Non omnes salvabuntur; ergo non omnes sunt praedestinati.'

37 SH I, P1, In1, Tr5, S2, Q4, Ti1, M2, C2 (n. 224), Respondeo, p. 320: 'Praescientia se habet aequaliter ad omnes, voluntas similiter uno modo se habet ad omnes; sed voluntas cum praescientia non se habet aequaliter ad omnes. Non tamen hoc est propter diversitatem quae sit in praescientia, sed quia nos non habemus nos aequaliter ad ipsam; unde praedestinatio non solum dicit voluntatem Dei, sed voluntatem cum praescientia quod bene usuri sunt dono suo.' 
Tim. 2:4. By His antecedent will, God does, in fact, will that all humans should be saved. 'For this is the will', the Summists explain, 'that considers the saveable rational creature', that is, the will that considers the salvific end for which all rational creatures are created and intended. ${ }^{38}$ But by God's consequent will, which includes foreknowledge concerning a particular rational creature's use of God's gift by means of his own free will, God wills that only the elect should be saved. It is in this way, the Summists note, that the will of God is called 'rational' (rationabilis) because it would be unjust for God to will final salvation for someone whom He knows will use the divine gift badly by means of his or her own free will. ${ }^{39}$ There is an important distinction here, then, between God's 'rational' will and God's will concerning the 'rational saveable creature'. It simply would not be reasonable, according to the Summists, for God to save all creatures, as He wills antecedently, if they themselves do not will to act according to this divine will. ${ }^{40}$

This same point is reiterated in the subsequent consideration of divine election. When it is asked, in Chapter 1 of Titulus 3, whether election should be placed or located in God, the second objection offers 1 Tim. 2:4 as evidence that the will of God is 'equal' or 'just' (aeque) with regard to all in order that all might be saved..$^{41}$ The respondeo explains that election is the preferential choosing of one of two options that lie before someone, and that this choosing can happen in one of two ways: either 'by prior deliberation' (praecedente deliberatione) or 'by prior certain knowledge' (praecedente certa cognitione). Whereas we humans elect in the first way, with consideration or consultation in time concerning doubtful or contingent things, God does so in the second way, with sure knowledge and outside of time. ${ }^{42}$ But God's certain, eternal cognitio 'sees beforehand', as it were, every human person's deliberations and actions concerning the divine salvific will for humankind; and so God's eternal election takes account of each human's temporal elections, as it were. Simply stated, human election matters greatly to divine election. Indeed, in reply to the first two objections, the Summists affirm: 'It must be said that the will of God orients itself equally toward

38 SH I, P1, In1, Tr5, S2, Q4, Ti1, M2, C2 (n. 224), Respondeo, p. 320: '(...) voluntate antecedente "vult Deus omnes homines salvos fieri”; haec enim est voluntas quae respicit creaturam rationalem salvabilem.'

39 SH I, P1, In1, Tr5, S2, Q4, Ti1, M2, C2 (n. 224), Respondeo, p. 320: ‘(...) et sic dicitur voluntas Dei rationabilis; si enim vellet alicui finaliter salutem qui male usurus est per liberum arbitrium, non esset iusta.'

40 For a fuller engagement with Damascene's distinction between God's antecedent and consequent will, and with 1 Tim. 2:4 in the context of this distinction, see the consideration 'De voluntate beneplaciti' in SH I, P1, In1, Tr6, Q3, Ti2, M1 (n. 273), pp. 372-5.

41 SH I, P1, In1, Tr5, S2, Q4, Ti3, C1 (n. 241), arg. 2, p. 334: '(...) sed aeque est voluntas Dei respectu omnium ut salventur, quia "vult omnes homines salvos fieri”, et aequa est ratio, constat, respectu omnium; ergo restat quod apud ipsum non sit electio.'

42 SH I, P1, In1, Tr5, S2, Q4, Ti3, C1 (n. 241), Respondeo, p. 334: '(...) sed hoc potest esse dupliciter: praecedente deliberatione vel praecedente certa cognitione. Primo modo est electio in nobis, secundo modo in Deo.' 
all [humans], but not all [humans] orient themselves equally toward Him. ${ }^{33}$ What distinguishes the elect human from the non-elect one is precisely that the former 'finally remains in grace', whereas the latter does not; and this ultimate abiding in God's supernatural gift constitutes, from the human side of this sacred mystery, the grounds upon which the human who is divinely chosen is chosen. ${ }^{44}$

Furthermore, human elections vis-à-vis God's salvific will matter not only to divine election, but also, a fortiori, to reprobation. The Summists locate reprobation in the genus of 'practical foreknowledge', as it has to do fundamentally with God's eternal knowledge of human action or practice. But, like predestination, reprobation is also a kind of 'volitional knowledge'. Indeed, our authors teach that reprobation is 'not in the genus of foreknowledge of a simple notion, but in the genus of foreknowledge not only with approbation but also with detestation: for it is knowledge with approbation of punishment and with detestation of iniquity. ${ }^{95}$ Whereas predestination is divine foreknowledge only with approbation, reprobation entails divine detestation as well. But the $S H$ is quick to point out that God's hatred of human iniquity and corresponding approval of punishment for such wickedness is a good. The Summists teach explicitly here that God is not the cause of evil; but, because punishment falls in the genus of the good, God can be said to be the efficient cause (causa effectiva) of it, just as God is the efficient cause of all good. However, the fault or offense (culpa) of the human who is reprobate is the meritorious cause (causa meritoria) of his or her ultimate punishment. ${ }^{46}$

The picture is still more causally complicated, however, in that reprobation requires not only the human's final withdrawal from grace, but also God's withdrawal of grace from the human. Recognizing that the 'withdrawal of grace' (subtractio gratiae) is the effect of reprobation, the Summists ask whether this effect is from God. Can this withdrawal of grace from the human who is to be reprobate be attributed in any way to God? Instead of offering a single, direct determination of this difficult question, our authors briefly set forth three ways that the question has been answered by certain others. The first two solutions, which do not demand our attention here, may be identified with William of Auxerre and Praepositinus of Cremona, respectively. The third, which seems to be the Summists' preferred solution, teaches that the 'non-gift of grace' (non-appositio gratiae)-that is, God's withholding of grace from some-can be considered in two ways, namely in terms of absolute

43 SH I, P1, In1, Tr5, S2, Q4, Ti3, C1 (n. 241), Ad obiecta 1-2, p. 334: 'dicendum quod voluntas Dei aequaliter se habet ad omnes, sed non omnes aequaliter se habent ad ipsum.'

44 SH I, P1, In1, Tr5, S2, Q4, Ti3, C1 (n. 241), Ad obiecta 1-2, p. 334: '(...) iste finaliter manet in gratia, ille non: et ideo iste eligitur, ille non' (emphasis mine).

45 SH I, P1, In1, Tr5, S2, Q4, Ti2, C2 (n. 235), Respondeo, p. 329: 'Ipsa est in genere praescientiae practicae, et non in genere praescientiae simplicis notitiae, sed in genere praescientiae, non cum approbatione solum, sed etiam cum detestatione: est enim scientia cum approbatione poenae et cum detestatione iniquitatis.'

46 SH I, P1, In1, Tr5, S2, Q4, Ti2, C2 (n. 235), Respondeo, p. 329. 
being (in esse absoluto) and in terms of ordained being (in esse ordinato). If the nongift is considered in terms of absolute being, the hardening experienced by the reprobate is not from God, as the non-gift is no thing, a privation of the good. If, on the other hand, the non-gift is considered insofar as it has being in a particular order and has 'the being of punishment' (esse poenae), it is from God. ${ }^{47}$ Thus, the Summists conclude: 'For God ordains this privation, which is a punishment, by reason of His own justice. ${ }^{48}$

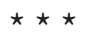

In his 1920 revision of Die protestantische Ethik und der Geist des Kapitalismus, the German sociologist Max Weber painted a starkly fatalistic and individualistic picture of the doctrine of predestination as understood, and lived, by the early-modern followers of John Calvin:

The Father in heaven of the New Testament, so human and understanding, who rejoices over the repentance of a sinner as a woman over the lost piece of silver she has found, is gone. His place has been taken by a transcendental being, beyond the reach of human understanding, who with His quite incomprehensible decrees has decided the fate of every individual and regulated the tiniest details of the cosmos from eternity. God's grace is, since His decrees cannot change, as impossible for those to whom He has granted it to lose as it is unattainable for those to whom He has denied it. ${ }^{49}$

This unscriptural doctrine is, according to Weber, characterized by an 'extreme inhumanity' that led its adherents to an 'unprecedented inner loneliness' and an utter isolation vis-à-vis their salvation. The individual Christian was 'forced to follow his path alone to meet a destiny which had been decreed for him from eternity'. ${ }^{50}$ For Weber, no one and no thing-no priest, no sacraments, no Church, not even God Himselfcould be of any help whatsoever to the human whose destiny had long been determined to be damnation. ${ }^{51}$

When, over a half-century later, W.H.C. Frend claimed that Augustine 'left the Middle Ages with a theological legacy of arbitrary predestination', ${ }^{52}$ he seems to have assumed the late Augustine's teaching, which certainly shaped the modern Calvinist account. And, indeed, it is not difficult to see how Frend might have supposed

47 SH I, P1, In1, Tr5, S2, Q4, Ti2, C3 (n. 236), Respondeo, p. 330: 'Si consideretur in esse absoluto, obduratio non est a Deo; sed secundum quod habet esse in ordine et habet esse poenae, sic est a Deo.'

48 SH I, P1, In1, Tr5, S2, Q4, Ti2, C3 (n. 236), Respondeo, p. 330: ‘(...) ex iustitia enim sua ordinat hanc privationem, quae poena est.'

49 Max Weber, The Protestant Ethic and the Spirit of Capitalism, trans. Talcott Parsons (New York: Charles Scribner's Sons, 1958), 103-4.

50 Weber, The Protestant Ethic, 104.

51 Weber, The Protestant Ethic, 104-5.

52 Frend, The Early Church, 198. 
this account to be thoroughly pessimistic, fatalistic, and irrational. But, as I have sought to demonstrate, medieval scholastic theologians such as the authors of the Summa Halensis would have found this modern Calvinist interpretation strangely flat-footed and theologically problematic, particularly in light of the early-medieval conciliar tradition concerning predestination they had received. The Second Council of Orange (529) and the Synods of Quiercy (853) and Valence (855), for example, made clear that divine grace is primary in leading the predestined to final salvation, on the one hand, and that the culpable rejection of this grace, offered antecedently, is essential to the ultimate damnation of the reprobate, on the other. ${ }^{53}$

In line with this conciliar doctrine, the $S H$ teaches that predestination is God's eternal 'volitional knowledge' of those humans who will, by their free wills, use well the grace prepared for them to attain finally to glory. Following closely the scriptural witness and Augustine's classic definition, the early Franciscan school seems to have understood well the necessity, in explicating the doctrine of predestination, to balance carefully its eternal core, as it were, with its temporal causes and effects, that is, its divine causality with the indispensable human contribution. Indeed, the Summa's interpretation of 1 Tim. 2:4, aided by Damascene's distinction, serves as a necessary fulcrum for this delicate balancing act: although God's (antecedent) will for the 'saveable rational creature' is universal salvation, this selfsame divine will is 'rational'-that is, justonly if salvation is limited to those whom God knows will (consequently) use grace and their own free wills well.

It is significant, particularly in light of the late Augustine's insistence that predestination is not essentially God's foreknowledge of what humans are going to do, that the $S H$ understands predestination 1. as pertaining first and foremost to divine knowledge, rather than divine will, and 2. as a doctrine aiming at inculcating Christian belief toward justice. For the Summists, both predestination and reprobation are manifestations of God's perfect love, goodness, and rationality or justice. In the case of reprobation, God's hatred of human iniquity and approval of punishment for it are located in the genus of the good. The non-gift of grace to the reprobate in esse absoluto is not from God, as it is simply a privation, a lack of being. But insofar as it is in esse ordinato, that is, ordered to punishment, it is from God and exists by reason of God's justice, which is reason itself. ${ }^{54}$ Indeed, when the Summists ask 'whether there is a cause or reason of the divine will', they maintain, aided by Anselm, that the divine will should not, properly speaking, be said to be either 'from

53 See White, 'Catholic Predestination,' 95-6, and, for the synodal declarations, Heinrich Denzinger, Compendium of Creeds, Definitions, and Declarations on Matters of Faith and Morals, ed. Peter Hünermann, Robert Fastiggi, and Anne Englund Nash, 43rd ed. (San Francisco: Ignatius Press, 2012), nn. 373-97, 621-4, and 625-33; see especially Synod of Quiercy, Chapters 1 and 3, the latter of which provides a summary interpretation of 1 Tim. 2:4 (Denzinger, Compendium, nn. 621 and 623). 54 See also SH I, P1, In1, Tr6, Q3, Ti2, M2, C2, Ar3 (n. 279), Respondeo, pp. 386-7, where, in response to the question, 'By what reason does God permit evil things to happen?', our authors answer, in thoroughly Augustinian terms, that evil happens by reason of the good in which it always exists. 
reason' (ex ratione), as if from some other principle, or 'beyond reason' (praeter rationem), lest it might seem irrational; rather, it is absolutely identical with reason. ${ }^{55}$ Thus, over against the popular modern perspective that understands predestination as 'arbitrary' and irrational, the $S H$ argues that God's predestinating will is perfectly rational, and indeed is reason itself.

As I have aimed to show, the $S H$ builds this argument for predestination's rationality to a significant degree on the way in which it makes room for genuine human freedom to will and to act. Nearly all of the questions treated above emphasize both sides, as it were, of the predestination equation - the eternal and the temporal, the divine and the human-and the necessary balance and interrelation between the two. The heart of the modern critique of both the late Augustine and Calvinism is that God's eternal decree renders each human's life and its end a fait accompli that precludes true and efficacious human freedom. The $\mathrm{SH}$ seems to have anticipated this critique by some 800 years, and offers what I take to be a convincing alternative to the late Augustine. Today's popular view of predestination, forged in the fire of Augustinian doctrine and Calvinist history, imagines God's eternal decree as a kind of ur-event on the same temporal plane with all human willing and doing. And so, if God 'before all time' chose some humans for everlasting life and others for reprobation, individual humans can do nothing either to effect or to overturn this salvation or damnation, respectively. Divine willing and acting, on the one hand, and human willing and acting, on the other, are imagined as in competition with one another in a kind of zero-sum game. The $S H$, by contrast, assumes a metaphysical picture of reality according to which 1 . true human freedom of willing and acting is impossible without God's willing and acting eternally (that is, completely outside of time), and 2. God's eternal 'volitional knowledge' of each human requires and necessarily takes into account that particular human's free willing and acting in time. Here the model of the relationship between the eternal and the temporal, the divine and human, is not competitive, but rather cooperative or concurrent. ${ }^{56}$ With this fundamental assumption of divine-human concurrence in hand, the authors of the Summa Halensis developed a doctrine of predestination that effectively defused the theological dynamite set by the late Augustine.

55 SH I, P1, In1, Tr6, Q2, C3 (n. 271), Respondeo, p. 366.

56 Subsequent scholastic theologians likewise assumed and further developed this understanding of divine-human concurrence in the context of providence, predestination, and other doctrines. In Aquinas, e. g.; see, for instance, Thomas Aquinas, Summa contra Gentiles 1.15, 2.48, 3.77-83 and 94-96, in Latin/English Edition of the Works of St. Thomas Aquinas, vols 11 and 12, trans. Fr. Laurence Shapcote (Green Bay, WI: Aquinas Institute, 2018), 11:27-8, 241-2 and 12:147-60, 184-97; and Thomas Aquinas, Summa Theologiae I, q. 14, a. 13; q. 19, aa. 7-8; q. 23, esp. aa. 5-6; q. 83, a. 1; and q. 105, a. 5, in Latin/English Edition of the Works of St. Thomas Aquinas, vols 13 and 14, ed. John Mortensen and Enrique Alarcón, trans. Fr. Laurence Shapcote (Lander, WY: Aquinas Institute, 2012), 13:164-7, 218-21, 257-62 and 14:317-9, 517-9; see also Eleonore Stump, Aquinas (London: Routledge, 2003), 131-58; and Michael J. Dodds, The Unchanging God of Love: Thomas Aquinas and Contemporary Theology on Divine Immutability, 2nd ed. (Washington, DC: The Catholic University of America Press, 2008), 183-98. 